\title{
ANALISIS FAKTOR-FAKTOR YANG MEMPENGARUHI AUDIT DELAY (Studi Empiris pada Perusahaan Consumer Goods yang Terdaftar di Bursa Efek Indonesia (BEI) Periode 2012-2015)
}

\author{
Hari Purnama \\ Universitas PGRI Yogyakarta, Jl. PGRI I No.117 Sonosewu, Yogyakarta. \\ email: haripurnama272@gmail.com
}

\begin{abstract}
Abstrak
Tujuan penelitian ini untuk mengetahui bukti empiris pengaruh ukuran perusahaan, profitabilitas, solvabilitas, laba/rugi, opini auditor, dan reputasi KAP terhadap audit delay.

Jenis penelitian ini adalah esplanatif, variabel penelitian ukuran perusahaan, profitabilitas, solvabilitas, laba/rugi, opini auditor, reputasi KAP dan audit delay. Populasi penelitian ini adalah perusahaan Consumer Goods Go Public yang sahamnya secara aktif diperdagangkan selama 5 tahun berturut-turut yaitu dari tahun 2012 sampai dengan tahun 2015, sedangkan sampel sebagian dari populasi yang sesuai kriteria yang ditentukan. Teknik pengambilan sampel purposive sampling. Teknik pengumpulan data dengan metode dokumentasi berupa anual report perusahaan sampel. Teknik analisis data regresi linier berganda, dengan tingkat signfiikansi 5\%, dimana dalam uji regresi tersebut akan diuji pengaruh antara variabel independen terhadap variabel dependen. Namun sebelumnya akan diuji terlebih dahulu uji normalitas, uji multikolinearitas, uji heteroskedastisitas dan uji autokorelasi.

Hasil penelitian menunjukkan faktor yang tidak berpengaruh terhadap audit delay adalah solvabilitas dan reputasi KAP. Sedangkan ukuran perusahaan, profitabilitas, laba/rugi, dan opini auditor berpengaruh signifikan terhadap audit delay. Semua faktor mempunyai pengaruh negatif yaitu ukuran perusahaan, ptofitabilitas, solvabilitas, laba/rugi, opini auditor, dan reputasi KAP.
\end{abstract}

Kata Kunci: Ukuran Perusahaan, Ptofitabilitas, Solvabilitas, Laba/Rugi, Opini Auditor, Reputasi KAP dan Audit Delay.

\begin{abstract}
The purpose of this study is determine the effect of firm size empirical evidence, profitabilitas, solvency, profit / loss, the auditor's opinion, and the reputation of KAP audit delay.

The type of this research is esplanatif, variable research firm size, ptofitabilitas, solvency, profit / loss, the auditor's opinion, the reputation of KAP and audit delay. The study population was Consumer Goods companies go public whose shares are actively traded for 5 consecutive years ie from 2012 to 2015, while the majority of the population samples that match the criteria specified the sampling collcting data is purposive sampling technique. Data collection techniques with methods of documentation in the form of sample company anual report. The data analysis techniques are multiple linear regression, with signfiikansi rate of 5\%, which in the regression test to test the influence of the independent variables on the dependent variable. Meanwhile, it will be tested first before normality test, multicollinearity, heteroscedasticity test and autocorrelation test.

The results showed that the factors do not affect the audit delay is solvency and reputation of KAP. Meanwhile, company size, profitability, profit / loss, and the auditor's
\end{abstract}


opinion significantly influence audit delay. All of these factors have a negative impact, which are the size of the company, profitabilitas, solvency, profit / loss, the auditor's opinion, and the reputation of KAP.

Keywords: Company size, Profitability, Solvability, Profit / Loss, Auditor opinion, reputation of KAP, and Audit Delay.

\section{Pendahuluan}

\section{Latar Belakang Masalah}

Perkembangan pasar modal di Indonesia berdampak peningkatan permintaan akan audit laporan keuangan. Setiap perusahaan yang terdaftar di Bursa Efek Indonesia setiap tahun diwajibkan untuk menyampaikan laporan tahunan (annual report) kepada Bursa Efek Indonesia (BEI) dan para pemodal (stockholder). Menurut Keputusan Ketua BAPEPAM No. Kep-36/PM/2003, No. 1 Peraturan X.K.2 tentang Kewajiban Penyampaian Laporan Keuangan Berkala, menyatakan laporan keuangan berkala disertai dengan Laporan Akuntan disampaikan kepada BAPEPAM selambat-lambatnya pada akhir bulan ketiga setelah tanggal laporan keuangan tahunan. Hasil audit atas perusahaan wajib diumumkan ke publik paling tidak melalui 2 surat kabar harian berbahasa Indonesia, secara periodik dan tepat waktu. Hasil ini mempunyai konsekuensi dan tanggung jawab yang besar agar memacu audit untuk bekerja secara lebih profesional (Kartika, 2011).

Salah satu kriteria profesionalisme dari auditor adalah ketepatan waktu penyampaian laporan auditnya. Ketepatan waktu perusahaan dalam mempublikasikan laporan keuangan kepada masyarakat umum dan kepada BAPEPAM juga tergantung dari ketepatan waktu auditor dalam menyelesaikan pekerjaan auditnya. Ketepatan waktu ini terkait dengan manfaat dari laporan keuangan itu sendiri.

Ketepatan waktu penyusunan atau pelaporan suatu laporan audit atas laporan keuangan perusahaan bisa mempengaruhi pada nilai laporan keuangan tersebut. Keterlambatan informasi akan menimbulkan reaksi negatif dari perilaku pasar modal, karena laporan keuangan audit yang di dalamnya memuat informasi penting, seperti laba yang dihasilkan perusahaan bersangkutan dijadikan sebagai salah satu dasar pengambilan keputusan untuk membeli atau menjual kepemilikan yang dimiliki oleh investor, artinya informasi laba dari laporan keuangan yang dipublikasikan akan menyebabkan kenaikan atau penurunan harga saham. Rentang waktu antara tanggal laporan keuangan dengan tanggal laporan opini auditor dalam terminology penelitian pengauditan dikenal dengan audit delay. Dengan kata lain, audit delay adalah waktu yang dibutuhkan oleh auditor untuk mengaudit laporan keuangan sejak tanggal laporan keuangan. Semakin lama waktu yang diperlukan oleh auditor untuk mengaudit, semakin panjang pula audit delay. Audit Delay yang melewati batas waktu ketentuan BAPEPAM akan berakibat pada keterlambatan publikasi laporan keuangan. Keterlambatan publikasi laporan keuangan tersebut dapat mengindikasikan adanya masalah dalam laporan keuangan, sehingga memerlukan waktu yang lebih lama dalam penyelesaian audit. Atas dasar latar belakang diatas, maka peneliti mengangkat judul "Analisis Faktor-Faktor yang Mempengaruhi Audit Delay pada Perusahaan Consumer Goods yang Terdaftar pada BEI periode 2012-2015."

\section{Rumusan Masalah}

Berdasarkan uraian latar belakang masalah di atas, maka rumusan masalah penulisan skripsi ini adalah :

1) Apakah ukuran perusahaan berpengaruh terhadap audit delay?

2) Apakah profitabilitas berpengaruh terhadap audit delay?

3) Apakah solvabilitas berpengaruh terhadap audit delay? 
4) Apakah laba dan rugi perusahaan berpengaruh terhadap audit delay?

5) Apakah opini auditor berpengaruh terhadap audit delay?

6) Apakah reputasi KAP berpengaruh terhadap audit delay?

\section{Pengembangan Hipotesis}

\section{Pengaruh Ukuran Perusahaan terhadap Audit delay}

Perusahaan besar akan mempublikasikan laporan keuangan dan laporan auditor lebih cepat dari pada perusahaan kecil karena manajemen perusahaan yang berskala besar cenderung diberikan insentif untuk mengurangi audit delay. Perusahaan besar cenderung mengalami tekanan eksternal yang lebih tinggi dari pihak investor, pengawas permodalan dan pemerintah untuk mengumumkan audit lebih awal (Santoso, 2012). Ukuran perusaahan dapat dilihat dari seberapa banyak perusahaan mempunyai sejumlah informasi mengenai kompleksitas operasional dan intensitas transaksi perusahaan. Perusahaan dengan ukuran perusahaan yang besar cenderung akan lebih tepat waktu dalam melakukan auditnya. Perusahaan besar berada dibawah tekanan untuk mengumumkan laporan keuangannya tepat waktu untuk menghindari adanya spekulasi dalam perdagangan saham perusahaannya (Owusuansah, 2000 dalam Dewi dan Pamudji, 2013). Menurut Dyer dan Mc Hugh, 1975 dalam Kartika, 2011) perusahaan besar lebih konsisten untuk tepat waktu dibandingkan perusahaan kecil dalam menginformasikan laporan keuangannya.

Faktor Ukuran Perusahaan merupakan salah satu faktor yang sering diteliti pada peneleitian sebelumnya. Hasil penelitian Kartika (2011), Santoso (2012), Estrini dan Laksito (2013), Dewi dan Pamudji (2013), dan Saputri (2012) menyebutkan bahwa audit delay memliliki hubungan negatif dengan ukuran perusahaan. Hal ini disebabkan karena perusahaan besar memiliki sistem pengendalian intern yang baik dan memadai sehingga dapat mengurangi tingkat kesalahan penya- jian laporan keuangan perusahaan, karena pengendalian intern merupakan proses yang dilakukan perusahaan guna menjaga keandalan laporan keuangan perusahaan dan kepatuhan terhadap hukum sehingga dapat memudahkan auditor dalam melakukan proses audit. Berdasarkan uraian tersebut, hipotesis yang diajukan:

$\mathbf{H}_{1}$ : Ukuran Perusahaan berpengaruh negatif terhadap audit delay.

\section{Pengaruh Profitabilitas terhadap Audit Delay}

Perusahaan yang memiliki tingkat profitabilitas tinggi membutuhkan waktu audit lebih cepat, hal ini dikarenakan adanya pertanggung jawaban untuk menyampaikan good news sehingga cenderung menyerahkan laporan keuangannya tepat waktu. Jika perusahaan melaporkan laba tinggi maka perusahaan mengharapkan laporan keuangan auditan segera diselesaikan agar good news dapat segera dipublikasikan kepada pihak-pihak yang berkepentingan. Perusahaan tidak akan menunda penyampaian informasi yang berisi berita baik. Oleh karena itu, perusahaan yang mampu menghasilkan profit akan cenderung mengalami audit delay yang lebih pendek, sehingga good news tersebut dapat segera disampaikan kepada para investor dan pihak-pihak yang berkepentingan lainnya. Sebagai dasar pemikiran bahwa tingkat keuntungan dipakai salah satu cara untuk menilai keberhasilan efektivitas perusahaan, tentu saja berkaitan dengan hasil akhir dari berbagai kebijakan dan keputusan perusahaan yang telah dilaksanakan oleh perusahaan dalam periode berjalan. Perusahaan yang profitable memiliki insentif untuk menginformasikan ke publik kinerja unggul mereka dengan mengeluarkan laporan tahunan secara cepat (Kartika, 2011).

Profitabilitas menunjukkan keberhasilan perusahaan dalam memperoleh keuntungan. Semakin tinggi rasio profitabilitas maka semakin tinggi pula tingkat efisiensi kinerja perusahaan dalam menghasilkan keuntungan. Sebaliknya jika perusahaan memiliki 
tingkat profitabilitas rendah maka perusahaan akan cenderung melaporkan laporan keuangannya tepat waktu. Hal tersebut sejalan dengan penelitian yang dilakukan oleh Kartika (2011), Santoso (2012), Estrini dan Laksito (2013), Hermiyatti dan Savitri (2012), yang menyatakan bahwa profitabilitas berpengaruh negatif terhadap audit delay. Berdasarkan uraian tersebut, hipotesis yang diajukan:

\section{$\mathbf{H}_{\mathbf{2}}$ : Profitabilitas berpengaruh negatif terhadap audit delay.}

\section{Pengaruh Solvabilitas terhadap Audit Delay}

Solvabilitas seringkali disebut leverage ratio. Weston dan Copeland (1995) dalam Kartika (2011) menyatakan bahwa rasio leverage mengukur tingkat aktiva perusahaan yang telah dibiayai oleh penggunaan utang. Dengan demikian solvabilitas merupakan kemampuan suatu perusahaan untuk membayar semua utang-utangnya baik jangka pendek maupun jangka panjang. Tingginya rasio debt to equity mencerminkan tingginya resiko keuangan perusahaan. Tingginya resiko ini menunjukkan adanya kemungkinan bahwa perusahaan tersebut tidak bisa melunasi kewajiban atau utangnya baik berupa pokok maupun bunga. Resiko perusahaan yang tinggi mengindikasikan bahwa perusahaan mengalami kesulitan keuangan.

Penelitian yang dilakukan oleh Santoso (2012) mengenai faktor-faktor yang mempengaruhi audit delay. Penelitian ini dilakukan dengan obyek laporan keuangan auditan yang terjadi pada perusahaan manufaktur. Hasil penelitian variabel solvabilitas merupakan proporsi total utang atas asset memiliki pengaruh signifikan. Apabila perusahaan memperoleh laba tinggi maka perusahaan akan berkeinginan agar good news segera dipublikasikan kepada investor maupun pihak yang berkepentingan. Solvabilitas merupakan rasio yang menggambarkan seberapa besar ketergantungan perusahaan terhadap kewajiban untuk membiayai asset dan operasional perusahaan. Semakin tinggi utang yang dimiliki perusahaan maka audit delay semakin pendek. Hal ini sesuai dengan penelitian yang dilakukan oleh Dewi dan Pamudji (2013), Kartika (2011) dan Santoso (2012) yang menyatakan bahwa solvabilitas berpengaruh negatif terhadap audit delay. Berdasarkan uaraian tersebut, hipotesis yang diajukan:

$\mathbf{H}_{3}$ : Solvabilitas berpengaruh negatif terhadap audit delay.

\section{Pengaruh Laba Rugi Perusahaan terhadap Audit Delay}

Perusahaan yang mengalami kerugian akan meminta auditor untuk mengatur auditnya lebih lama agar dapat memperlambat penerbitan laporan keuangan perusahaan. Sebaliknya apabila perusahaan mengalami laba akan meminta auditor untuk mempercepat auditnya. Hal ini disebabkan ketika terjadi kerugian, perusahaan ingin menunda bad news sehingga perusahaan akan meminta auditor untuk mengatur waktu auditnya lebih lama dibandingkan biasanya. Sebaliknya, jika perusahaan mengalami laba tinggi maka tidak ada alasan untuk perusahaan menunda penerbitan laporan keuangannya. Laba tinggi akan mempercepat proses auditnya, sehingga good news dapat dipublikasikan dengan segera kepada pihak investor dan pihak-pihak lainnya yang berkepentingan.

Menurut Ashton, et. al., 1987 dalam Melinda (2015) perusahaan yang mendapatkan laba tidak ada alasan untuk menunda penerbitan laporan keuangan auditan karena hal tersebut merupakan berita baik atau prestasi yang dicapai suatu perusahaan cukup menggembirakan sehingga perusahaan yang mendapatkan laba akan mengalami audit delay yang lebih pendek. Hal ini sejalan dengan penelitian Kartika (2011), bahwa profit or loss berpengaruh terhadap audit delay. Sebaliknya, perusahaan yang mengalami kerugian akan berusaha memperlambat penerbitan laporan keuangan auditan. Alasannya adalah ketika terjadi kerugian perusahaan ingin menunda bad news sehingga perusahaan akan meminta auditor untuk mengatur waktu 
auditnya lebih lama dibandingkan biasanya.

Hal ini sejalan dengan penelitian Saputri (2012), Kartika (2011), Melinda (2015), yang menyatakan bahwa faktor laba rugi memiliki pengaruh negatif terhadap audit delay. Berdasarkan uraian tersebut, hipotesis yang diajukan:

$\mathbf{H}_{\mathbf{4}}$ : Laba Rugi Perusahaan berpengaruh negatif terhadap audit delay.

\section{Pengaruh Opini Auditor terhadap Audit Delay}

Carslaw dan Kaplan (1991) dalam Malinda (2015) menemukan adanya pengaruh antara opini audit dengan audit delay. Pada perusahaan yang menerima jenis pendapat qualified opinion akan menunjukan audit delay yang relatif lama, karena proses pemberian opini audit melibatkan negosiasi dengan klien, konsultasi dengan partner audit yang lebih senior atau staf teknis lainnya dan perluasan lingkup audit. Disamping itu penerimaan opini selain qualified merupakan indikasi terjadinya konflik antara auditor dan perusahaan yang pada akhirnya memperpanjang audit delay. Jadi, perusahaan yang tidak menerima opini audit standar unqualified opinion mengalami audit delay yang panjang.

Hasil penelitian tersebut sejalan dengan penelitian Utami (2006), Dewi dan Pamudji (2013), Kartika (2011) dan Melinda (2015) yang menyatakan bahwa opini auditor berpengaruh positif dan signifikan terhadap $a u$ dit delay. Apabila opini auditor wajar tanpa terkecuali, maka audit delay-nya semakin lama atau panjang. Berdasarkan uraian tersebut, hipotesis yang diajukan:

$\mathbf{H}_{5}$ : Opini auditor berpengaruh positif terhadap audit delay.

\section{Pengaruh Reputasi KAP terhadap Audit Delay}

Hasil penelitian Malinda, (2015), audit delay akan lebih pendek bagi perusahaan yang diaudit oleh KAP yang tergolong besar. Hasil yang sama juga ditemukan Ahmad dan Kartika (2011), audit delay pada KAP Big Four akan lebih pendek dibandingkan dengan audit delay pada KAP kecil. Hal ini dikarenakan KAP besar memiliki karyawan dalam jumlah yang besar, dapat mengaudit lebih efisien dan efektif, memiliki jadwal yang fleksibel sehingga memungkinkan untuk menyelesaikan audit tepat waktu, dan memiliki dorongan yang lebih kuat untuk menyelesaikan auditnya lebih cepat guna menjaga reputasinya. Penelitian yang dilakukan Estrini dan Laksito (2013) melakukan penelitian tentang Analisis Faktor-Faktor yang Mempengaruhi Audit Delay. Hasil penelitian ini menunjukkan profitabilitas, gender, dan reputasi KAP berpengaruh terhadap audit delay. Sedangkan ukuran perusahaan tidak mempunyai pengaruh terhadap audit delay. Rata-rata audit delay pada perusahaan sampel di Bursa Efek Indonesia periode 2009-2011 adalah 74,20 hari. Peneliti lain Saputri (2012) menyatakan bahwa reputasi KAP berpengaruh negatif terhadap audit delay. Sedangkan ukuran perusahaan, dan jenis industri tidak mempunyai pengaruh terhadap audit delay. Rata-rata audit delay yang terjadi pada perusahaan sampel di Bursa Efek Indonesia tahun 2009 adalah 75,975 hari. Perusahaan yang menggunakan auditor dengan anggota lebih besar, maka akan memperpendek penyelesaian auditan, Sebaliknya apabila perusahaan menggunakan auditor dengan anggota yang kecil maka waktu penyelesaian auditan menjadi panjang. Berdasarkan uraian tersebut, hipotesis yang diajukan:

$\mathbf{H}_{\mathbf{6}}$ : Reputasi KAP berpengaruh negatif terhadap audit delay.

\section{Metode Penelitian}

\section{Jenis penelitian}

Jenis penelitian yang digunakan adalah penelitian esplanatif yaitu merupakan jenis penelitian untuk mendapatkan penjelasan hubungan antar variabel atau penelitian untuk menguji dugaan sementara (hipotesis). 


\section{Variabel Penelitian}

Variabel penelitian ini adalah ukuran perusahaan, ptofitabilitas, solvabilitas, laba/ rugi, opini auditor, reputasi KAP dan audit delay.

\section{Populasi, Sampel dan Teknik Pengambilan Sampel}

Populasi yang digunakan adalah seluruh perusahaan Consumer Goods go public di Bursa Efek Indonesia. Elemen populasi yang digunakan dalam penelitian ini adalah perusahaan Consumer Goods Go Public yang sahamnya secara aktif diperdagangkan selama 5 tahun berturut-turut yaitu dari tahun 2012 sampai dengan tahun 2015. Teknik pengambilan sampel dilakukan dengan menggunakan metode purposive sampling.

\section{Definisi Operasional dan Pengukurannya}

\section{Variabel Dependen}

Variabel dependen dalam penelitian ini adalah audit delay yaitu jangka waktu penyelesaian audit laporan keuangan tahunan sejak tanggal penutupan tahun buku perusahaan sampai dengan tanggal yang tertera pada laporan auditor independent. Variabel ini diukur secara kuantitatif dalam jumlah hari antara tanggal penutupan tahun buku sampai tanggal penantanganan laporan auditan.

\section{Variabel Independen}

Variabel independen yang digunakan dalam penelitian ini adalah:

1. Ukuran Perusahaan $\left(\mathrm{X}_{1}\right)$, adalah besar kecilnya suatu perusahaan yang ditunjukkan oleh total aktiva, jumlah penjualan, rata-rata tingkat penjualan dan ratarata total aktiva. Ukuran perusahaan penelitian ini diukur dengan cara total penjualan bersih selama periode penelitian (2012-2015) kemudian di Logaritma Natural (LN). Rumus:

$$
\text { UP }=\text { Ln Net Sales }
$$

2. Profitabilitas $\left(\mathrm{X}_{2}\right)$, adalah rasio untuk mengukur besarnya kemampuan suatu perusahaan untuk memperoleh keuntungan ditinjau dari kemampuan perusahaan yang bersangkutan dalam memperoleh laba dibanding dengan jumlah aktiva yang dimilikinya. Profitabilitas penelitian ini diukur dari Rasio ROA yaitu net income dibagi dengan total asset. Perusahaan yang tingkat profitabilitasnya tinggi diduga waktu yang diperlukan untuk menyelesaian audit akan lebih pendek. Rumus:

\section{Profitabilitas $=\frac{\text { Net Income }}{\text { Total Asset }} \times 100 \%$}

3. Solvabilitas $\left(\mathrm{X}_{3}\right)$ adalah kemampuan suatu perusahaan untuk membayar semua utang-utangnya (berjangka pendek maupun jangka panjang. Solvabilitas dalam penelitian ini diukur dengan menggunakan debt total asset ratio. Rumus:

\section{Debt to Total Asset Ratio $=\frac{\text { Total Utang }}{\text { Total Aktiva }}$}

4. Laba atau rugi perusahaan $\left(X_{4}\right)$, adalah laporan keuangan perusahaan yang meringkaskan hasil dari kegiatan perusahaan yang sistematis tentang penghasilan, biaya, rugi laba yang diperoleh oleh suatu perusahaan selam periode tertentu. Laba atau rugi perusahaan dalam penelitian ini diukur dengan variabel dummy yaitu jika perusahaan yang mengalami rugi diberi kode (1) sedangkan perusahaan yang mengalami laba diberi kode (0).

5. Opini Auditor $\left(\mathrm{X}_{5}\right)$, adalah pernyataan kewajaran, dalam semua hal yang material, posisi keuangan, hasil usaha dan arus kas sesuai dengan prinsip akuntansi berterima umum. Opini auditor diukur dengan opini wajar tanpa pengecualian diberi nilai 0 (nol) dan opini selain wajar tanpa pengecualian diberi nilai 1 (satu).

6. Reputasi $\operatorname{KAP}\left(\mathrm{X}_{7}\right)$, adalah tingkat reputasi KAP dalam menghasilkan kredibilitas laporan keuangan. Reputasi KAP diukur dengan perusahaan yang diaudit oleh KAP the Big Four diberi kode (1) 
sedangkan perusahaan yang diaudit oleh KAP lainnya diberi kode (0).

\section{Analisis Data}

Pengujian hipotesis dalam penelitian ini dilakukan model regresi linier berganda, dimana dalam uji regresi tersebut akan diuji pengaruh antara variabel independen terhadap variabel dependen. Namun sebelumnya akan diuji terlebih dahulu uji normalitas dan uji asumsi klasik yang meliputi uji multikolinearitas, uji heteroskedastisitas dan uji autokorelasi.

\section{Hasil Penelitian dan Pembahasan}

Statistik Diskriptif Variabel

Tabel 1. Descriptive Statistics Variabel.

\begin{tabular}{lrrrrr}
\hline & \multicolumn{1}{c}{$\boldsymbol{N}$} & Minimum & Maximum & Mean & Std. Deviation \\
\hline Size & 165 & 11,01 & 18,01 & 14,2495 & 1,83404 \\
Profitabilitas & 165 & $-1,07$ & 1,70 &, 1757 &, 27864 \\
Solvabilitas & 165 &, 05 & 5,04 &, 5496 &, 47297 \\
Laba/Rugi & 165 & 0 & 1 &, 92 &, 280 \\
Opini Auditor & 165 & 0 & 1 &, 96 &, 188 \\
Reputasi KAP & 165 & 0 & 1 &, 64 &, 481 \\
Audit Delay & 165 & 36 & 161 & 76,43 & 18,556 \\
Valid N (listwise) & 165 & & & & \\
\hline
\end{tabular}

\section{Uji Asumsi Klasik}

\section{Uji Normalitas}

\section{Uji Grafik}

Dilihat dari hasil grafik normalitas, maka data Normal P-P Plot of Regression Standardized Residual menunjukkan bahwa penyebaran data mendekati garis linier, sehing-ga penyebaran data dapat dilihat pada grafik berikut:

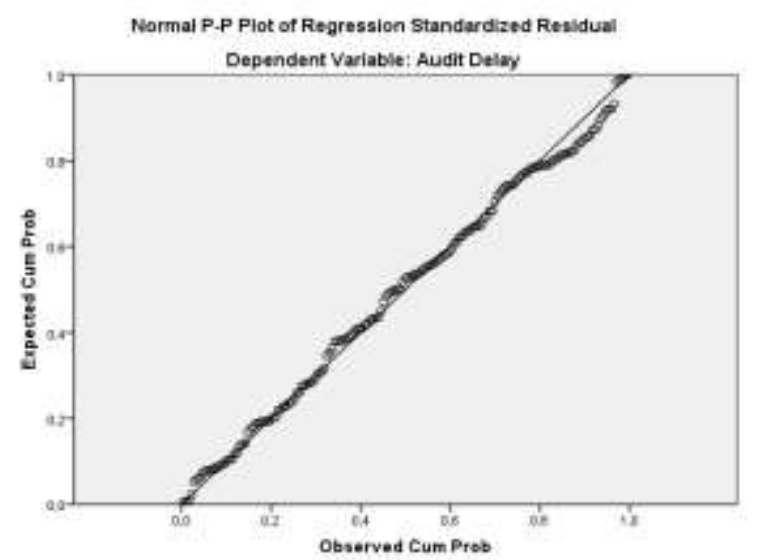

Gambar1. Uji Grafik Normalitas.

\section{Uji Statistik}

Dilihat dari uji statitik, dengan menggunakan uji One-Sample Kolmogorov-Smirnov Test, maka dapat dilihat pada tabel berikut:

Tabel 2. Uji Normalitas.

One-Sample Kolmogorov-Smirnov Test.

Unstandardized

Residual

$\mathrm{N}$ 165

Normal Mean

, 0000000

Parameters $^{\mathrm{a}, \mathrm{b}}$

Std.

15,47482240

Deviation

Most Extreme Absolute ,053

Differences Positive ,053

Negative $\quad-, 038$

Kolmogorov-Smirnov Z $\quad$,676

Asymp. Sig. (2-tailed) $\quad$,751

a. Test distribution is Normal.

b. Calculated from data. 
Nilai Kolmogrov-Smirnov $Z$ sebesar 0,676 dan nilai Asymp. Sig. (2-tailed) sebesar 0,751 yang diperoleh model regresi lebih dari $\alpha(0,05)$, berarti berdistribusi normal.

\section{Uji Multikolinieritas}

Tabel 3. Hasil Uji Multikolinieritas.

\begin{tabular}{llrr}
\hline \multirow{2}{*}{ Model } & \multicolumn{2}{c}{ Collinearity Statistics } \\
\cline { 3 - 4 } & Tolerance & VIF \\
\hline 1 & (Constant) & & \\
& Size &, 867 & 1,154 \\
& Profitabilitas &, 901 & 1,109 \\
Solvabilitas &, 933 & 1,072 \\
& Laba/Rugi &, 823 & 1,215 \\
Opini Auditor &, 968 & 1,033 \\
& Reputasi KAP &, 962 & 1,039 \\
\hline
\end{tabular}

Hasil diatas semua variabel bebas memiliki nilai VIF lebih kecil dari 10, sehingga dapat disimpulkan bahwa tidak ada gejala multikolinieritas.

\section{Uji Autokolerasi}

Tabel 4. Hasil Uji Autokolerasi.

\begin{tabular}{cc}
\hline $\begin{array}{c}\text { Nilai Durbin- } \\
\text { Watson }\end{array}$ & Keterangan \\
\hline 1,705 & Tidak ada Autokolerasi
\end{tabular}

Dari hasil output SPSS diatas dapat diketahui nilai DW sebesar dl $(1,66 \leq 1,705 \leq$ 4-du $(2,48)$, hal ini menunjukkan bahwa regresi tidak ada autokorelasi.

\section{Uji Heteroskedastisitas}

\section{Uji Grafik}

Dilihat dari grafik scater plot, penyebaran data menyebar dan tidak membentuk suatu pola, maka dapat disimpulkan bahwa data tidak terjadi heterokedatisitas. Berikut grafik scater plot dapat dilihat pada gambar berikut:

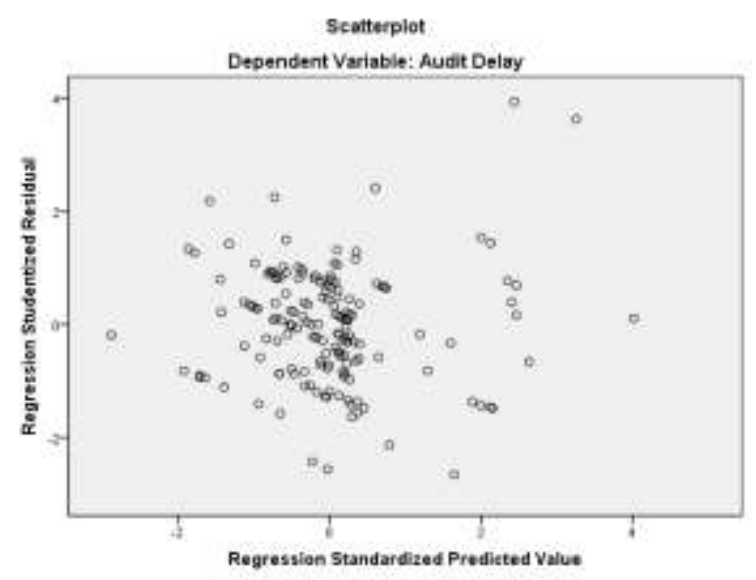

Gambar 2. Uji Grafik Scatterplot.

\section{Uji Statistik}

Dilihat dari uji statistik dengan meregresikan absolut residual maka dapat dilihat pada table berikut:

Tabel 5. Hasil Uji Heterokedatisitas.

\begin{tabular}{llrr}
\hline \multicolumn{1}{l}{ Model } & \multicolumn{1}{l}{$\boldsymbol{t}$} & \multicolumn{1}{c}{ Sig. } \\
\hline 1 & (Constant) & 2,537 &, 012 \\
& Size &,- 958 &, 339 \\
& Profitabilitas &,- 314 &, 754 \\
& Solvabilitas &, 625 &, 533 \\
& Laba/Rugi & $-1,312$ &, 192 \\
Opini Auditor &, 921 &, 359 \\
& Reputasi KAP &,- 665 &, 507 \\
\hline
\end{tabular}

Uji heteroskedastisitas menggunakan uji Glejser. Tabel 5. menunjukkan bahwa nilai signifikan semua variabel bebas lebih besar dari 0,05 ( $p>0,05)$, maka tidak signifikan, sehingga dapat disimpukan tidak ada gejala heteroskedastisitas.

\section{Analisis Data}

\section{Regresi Linier Berganda}

Persamaan regresi dari table 6 dibawah ini adalah:

$$
\begin{gathered}
Y=151,830-2,430 X_{1}-13,098 X_{2}-3,937 X_{3} \\
-17,450 X_{4}-19,236 X_{5}-2,798 X_{6}
\end{gathered}
$$


Tabel 6. Hasil Regresi Linier Berganda.

\begin{tabular}{lrrrrr}
\hline \multirow{2}{*}{ Model } & \multicolumn{2}{c}{$\begin{array}{c}\text { Unstandardized } \\
\text { Coefficients }\end{array}$} & $\begin{array}{c}\text { Standardized } \\
\text { Coefficients }\end{array}$ & \multirow{2}{*}{ t } & \multirow{2}{*}{ Sig. } \\
\cline { 2 - 4 } & \multicolumn{1}{c}{ B } & Std. Error & Beta & & \\
\hline (Constant) & 151,830 & 11,482 & & 13,223 &, 000 \\
Size & $-2,430$ &, 721 &,- 240 & $-3,371$ &, 001 \\
Profitabilitas & $-13,098$ & 4,654 &,- 197 & $-2,814$ &, 006 \\
Solvabilitas & $-3,937$ & 2,695 &,- 100 & $-1,461$ &, 146 \\
Laba/Rugi & $-17,450$ & 4,854 &,- 263 & $-3,595$ &, 000 \\
Opini Auditor & $-19,236$ & 6,665 &,- 195 & $-2,886$ &, 004 \\
Reputasi KAP & $-2,798$ & 2,611 &,- 072 & $-1,072$ &, 285 \\
\hline
\end{tabular}

\section{Uji t (Uji Hipotesis)}

\section{Pengaruh Ukuran Perusahaan terhadap Audit Delay}

Ukuran perusahaan mempunyai nilai $\mathrm{t}$ hitung $-3,371$ dan nilai signifikansi sebesar 0,001 lebih kecil dibanding probabilitas kesalahan sebesar 0,05 . Sehingga dapat disimpulkan bahwa ukuran perusahaan berpengaruh negatif dan signifikan terhadap audit delay. Dengan demikian hipotesis 1 yang dijabarkan diterima, hal ini mengandung makna bahwa besar kecilnya ukuran perusahaan mempengaruhi audit delay. Berdasarkan hasil pengujian hipotesis 1 dapat membuktikan bahwa hipotesis mendukung hubungan negatif dan signifikan antara ukuran perusahaan dengan audit delay. Hasil dari pengujian ini konsisten dengan penelitian Kartika (2011), Santoso (2012), Estrini dan Laksito (2013), Dewi dan Pamudji (2013), dan Saputri (2012) menemukan bahwa jenis perusahaan finansial mengalami audit delay yang lebih pendek dibandingkan dengan perusahaan-perusahaan dalam jenis industri lain. Hal ini disebabkan karena perusahaan besar memiliki sistem pengendalian intern yang baik dan memadai sehingga dapat mengurangi tingkat kesalahan penyajian laporan keuangan perusahaan, karena pengendalian intern merupakan proses yang dilakukan perusahaan guna menjaga keandalan laporan keuangan perusahaan dan kepatuhan terhadap hukum sehingga dapat memudahkan auditor dalam melakukan proses audit.

\section{Pengaruh Profitabilitas terhadap Audit Delay}

Profitabilitas mempunyai nilai $\mathrm{t}$ hitung $-2,814$ dan nilai signifikansi sebesar 0,006 lebih kecil dibanding probabilitas kesalahan sebesar 0,05. Sehingga dapat disimpulkan bahwa profitabilitas berpengaruh signifikan terhadap audit delay. Dengan demikian hipotesis 2 yang dijabarkan diterima, hal ini mengandung makna bahwa semakin besar profitabilitas maka semakin kecil atau semakin pendek audit delay. Hal ini menunjukkan bahwa pengaruh profitabilitas terhadap audit delay adalah semakin tinggi nilai rasio profitabilitas maka semakin panjang audit delay. Hal ini karena semakin tinggi profitabilitas atau laba suatu perusahaan maka pos-pos yang diaudit semakin banyak. Hasil penelitian ini mendukung peneliti terdahulu yang dilakukan oleh Estrini dan Laksito (2013), dan Hermiyetti dan Savitri (2009) yang menyatakan bahwa profitabilitas berpengaruh negtaif dan signifikan terhadap audit delay.

\section{Pengaruh Solvabilitas terhadap Audit Delay}

Solvabilitas mempunyai nilai $\mathrm{t}$ hitung -1,461 dan nilai signifikansi sebesar 0,146 lebih besar dibanding probabilitas kesalahan 
sebesar 0,05. Sehingga dapat disimpulkan bahwa solvabilitas tidak berpengaruh signifikan terhadap audit delay. Dengan demikian hipotesis 3 yang diajukan ditolak, hal ini mengandung makna bahwa semakin besar solvabilitas maka semakin kecil atau semakin pendek audit delay. Peningkatan jumlah utang akan memberikan tekanan pada perusahaan untuk mempublikasikan laporan keuangan lebih cepat agar jaminan dapat diberikan kepada para pemilik modal yang menginginkan pengurangan resiko premium dalam pengembalian modal mereka. Namun tidak signifikannya variabel debt to equity ratio dalam penelitian ini terjadi karena perusahaan dengan utang yang tinggi akan berusaha menyembunyikan resiko sehingga menunda publikasi laporan keuangan dengan harapan dapat mengurangi dampak negatif yang dapat membahayakan kelangsungan perusahaan tersebut. Hasil penelitian ini mendukung peneliti terdahulu yang dilakukan oleh Santoso (2012), yang menyatakan bahwa solvabilitas berpengaruh negtaif tidak signifikan terhadap audit delay.

\section{Pengaruh Laba/Rugi terhadap Audit Delay}

Laba/rugi mempunyai nilai $t$ hitung $-3,595$ dan nilai signifikansi sebesar 0,000 lebih kecil dibanding probabilitas kesalahan sebesar 0,05. Sehingga dapat disimpulkan bahwa laba/rugi berpengaruh signifikan terhadap audit delay. Dengan demikian hipotesis 4 yang diajukan diterima, hal ini mengandung makna bahwa semakin besar laba maka semakin kecil atau semakin pendek audit delay.

Perusahaan yang mendapatkan laba yang besar tidak ada alasan untuk menunda penerbitan laporan keuangan auditan bahkan cenderung untuk mempercepat penerbitan laporan keuangan auditan, karena perusahaan yang mengalami laba akan membuat investor menjadi senang dan calon investor akan tertarik untuk membeli saham sehingga akan menyebabkan kenaikan harga saham. Sebaliknya, perusahaan yang menderita kerugian akan berusaha memperlambat penerbitan laporan keuangan auditan. Auditor akan berhati-hati selama proses audit dalam merespon kerugian perusahaan apakah kerugian tersebut disebabkan oleh kegagalan finansial atau kecurangan manajemen.

\section{Pengaruh Opini Auditor terhadap Audit Delay}

Opini auditor mempunyai nilai t hitung $-2,886$ dan nilai signifikansi sebesar 0,004 lebih kecil dibanding probabilitas kesalahan sebesar 0,05. Sehingga dapat disimpulkan bahwa opini auditor berpengaruh signifikan terhadap audit delay. Dengan demikian hipotesis 5 yang dijabarkan diterima, hal ini mengandung makna bahwa apabila opini yang dibuat auditor wajar tanpa terkecuali maka semakin pendek audit delay. Hasil dari pengujian ini tidak konsisten dengan penelitian penelitian Kartika (2011), namun penelitian ini sesuai dengan penelitian Dewi dan Pamudji (2013), Kusumawardani (2013), dan Saputri (2012). Hal tersebut dikarenakan kondisi laporan keuangan antara tahun yang diaudit sekarang dengan yang lalu itu sama. Selain itu juga auditor akan bekerja secara profesional dalam menghadapi setiap kondisi perusahaan.

\section{Pengaruh Reputasi KAP terhadap Audit Delay}

Reputasi KAP mempunyai nilai t hitung -1,072 dan nilai signifikansi sebesar 0,285 lebih besar dibanding probabilitas kesalahan sebesar 0,05. Sehingga dapat disimpulkan bahwa Reputasi KAP tidak berpengaruh terhadap audit delay. Dengan demikian hipotesis 6 yang dijabarkan ditolak, hal ini mengandung makna bahwa besar kecilnya KAP atau Reputasi KAP tidak mempengaruhi audit delay. Perusahaan yang menggunakan auditor dengan anggota lebih besar, maka akan memperpanjang penyelesaian auditan, Sebaliknya apabila perusahaan menggunakan auditor dengan anggota yang kecil maka waktu penyelesaian auditan menjadi pendek. Hasil penelitian ini mendukung peneliti terdahulu yang dilakukan oleh Dewi dan Pamudji (2013) dan Mumpuni (2011) yang menyatakan bahwa reputasi KAP tidak berpengaruh terhadap audit delay. 


\section{Uji F}

Uji $\mathrm{F}$ digunakan untuk menganalisis besarnya pengaruh variabel independen terhadap variabel dependen. Secara menyeluruh hasil analisis dengan menggunakan model regresi linier berganda dapat dilihat pada tabel berikut:

Tabel 7. Hasil Uji-F dan Adjusted $R$ Square.

\begin{tabular}{ccc}
\hline Adjusted R Square & F & Sig. \\
\hline, 278 & 11,530 & $.000(\mathrm{a})$ \\
\hline
\end{tabular}

Dari tabel diatas dapat dilihat bahwa variabel independen yaitu ukuran perusahaan, profitabilitas, solvabilitas, laba/rugi, opini auditor, dan reputasi KAP secara simultan dan signifikan mempengaruhi audit delay yang ditunjukkan oleh signifikansi sebesar 0,000 lebih kecil dari probabilitas kesalahan yaitu 0,05 .

\section{Koefisien Determinasi}

Dari hasil analisis regresi yang dilakukan diperoleh adjusted $R$ Square sebesar 0,278 atau $27,8 \%$ yang artinya bahwa pengaruh variabel independen yaitu ukuran perusahaan, profitabilitas, solvabilitas, laba/ rugi, opini auditor, dan reputasi KAP terhadap audit delay sebesar 27,8\% sedangkan sisanya dipengaruhi oleh faktor lain yang tidak masuk dalam model penelitian.

\section{Simpulan}

Berdasarkan penelitian yang telah dilakukan diperoleh hasil-hasil sebagai berikut:

1) Ukuran perusahaan (Size) berpengaruh signifikan terhadap audit delay. Pengaruh ukuran perusahaan terhadap audit delay bersifat negtaif artinya semakin besar ukuran perusahaan maka semakin besar atau semakin pendek audit delay.

2) Profitabilitas berpengaruh singnifikan terhadap audit delay. Pengaruh profitabi- litas terhadap audit delay bersifat negatif artinya semakin besar profitabilitas maka semakin kecil atau semakin pendek audit delay.

3) Solvababilitas tidak berpengaruh singnifikan terhadap audit delay. Pengaruh solvabilitas terhadap audit delay bersifat negatif artinya semakin besar solvabilitas maka semakin kecil atau semakin pendek audit delay.

4) Laba/Rugi berpengaruh signifikan terhadap audit delay. Pengaruh laba/rugi terhadap audit delay bersifat negatif artinya apabila perusahaan laba maka semakin kecil atau semakin pendek audit delay.

5) Opini auditor berpengaruh singnifikan terhadap audit delay. Pengaruh opini auditor terhadap audit delay bersifat positif artinya apabila opini auditor wajar tanpa terkecuali maka semakin kecil besar atau semakin panjang audit delay.

6) Reputasi KAP tidak berpengaruh terhadap audit delay. Pengaruh reputasi KAP terhadap audit delay bersifat negatif artinya perusahaan yang menggunakan KAP the Big Four mempunyai audit delay semakin pendek.

\section{Daftar Pustaka}

Arens, Alvin A. Elder, Randal J. Beasley, Mark S. (2003). Auditing and Assurance Service an Integrated Approach. Ninth Edition. New Jersey: Printice Hall.

Brigham and Weston Houston. 2004. Manajemen Keuangan. Edisi Kedelapan. Jakarta: Penerbit Erlangga.

Dewi Karina Mutiara dan Pamudji Sugeng. 2013. Analisis Faktor-Faktor yang Mempengaruhi Ketepatan Waktu dan Audi Delay Penyampaian Laporan Keuangan pada Perusahaan Manufaktur yang Terdaftar di Bursa Efek Indonesia Periode 2007-2011. Journal of Accounting Vol. 2, No. 2, p. 1-13.

Estrini Dwi Hayu dan Laksito Herry. 2013. Analisis Faktor-Faktor yang 
Mempengaruhi Audit Delay. Journal of Accounting. Vol. 2, No. 2, p. 1.

Halim, Varianada. 2000. Faktor-faktor yang Mempengaruhi Audit Delay. Jurnal Bisnis dan Akuntansi. Vol. 2 No. 1, p. 6375 .

Hermiyetti dan Savitri Bunga Wildatika. 2009. Faktor-Faktor yang Mempengaruhi Audit Delay. Penelitian ini Mengambil Obyek pada Lembaga Keuangan yang Tercatat di Bursa Efek Indonesia Periode 2005-2007. Jurnal Ekubank, Vol. 2.

Imam, Shahed. 2001. Association of Audit Delay and Audit Firms' International Links: Evidence from Bangladesh. Managerial Auditing Journal 16/3, p. 129133.

Januarti, Indira. 2009. Analisis Pengaruh Faktor Perusahaan, Kualitas Auditor, Kepemilikan Perusahaan terhadap Penerimaan Opini Audit Going Concern (Perusahaan Manufaktur yang Terdaftar di Bursa Efek Indonesia). Simposium Nasional Akuntansi 12.

Jogiyanto, Hartono. 2008. Teori Portofolio dan Analisis Investasi. Edisi Kelima. Yogyakarta: BPFE.

Kartika Anda. (2011). Faktor-Faktor yang Mempengaruhi Audit Delay pada Perusahaan Manufaktur yang Terdaftar di $B E I$. Jurnal Dinamika Keuangan dan Perbankan. Vol. 3 No. 2, Hal: 152-171.

Kusumawardani. 2013. Faktor-Faktor yang Mempengaruhi Audit Delay pada Peru- sahaan Manufaktur. Journal of Accounting Vol. 2 No. 2, p. 15.

Malinda Dwi Apriliane. 2015. Analisis Faktor-Faktor yang Mempengaruhi Audit Delay (Studi Empiris pada Perusahaan Pertambangan yang Terdaftar di Bursa Efek Indonesia Tahun 2008-2013). Skripsi. Yogyakarta: Fakultas Ekonomi Universitas Negeri Yogyakarta.

Mumpuni. 2011. Pengaruh Ukuran Perusahaan, Keberadaan Komite Audit, Laba Rugi Perusahaan, Ukuran Auditor, dan Opini Auditor terhadap Audit Delay pada Perusahaan Non Keuangan yang Terdaftar di Bursa Efek Indonesia Periode 2006-2008. Journal of Accounting Vol. 2, No. 2.

Praptitorini, Mirna Dyah dan Indira Januarti. 2007. Analisis Pengaruh Kualitas Audit, Debt Default, dan Opinion Shopping terhadap Penerimaan Opini Going Concern. Disampaikan pada Simposium Nasional Akuntansi (SNA) X Makassar.

Santoso, Felisiane Kurnia. 2012. Analisis Faktor-Faktor yang Mempengaruhi Audit Delay pada Perusahaan di Sektor Keuangan. Jurnal Berkala Ilmiah Mahasiswa Akuntansi. Vol. 1 No. 2.

Saputri Oviek Dewi. 2012. Faktor-Faktor yang Mempengaruhi Audit Delay Studi Empiris Perusahaan-Perusahaan yang Terdaftar di Bursa Efek Indonesia. Journal of Accounting. Vol. 2 No. 2.

Sugiyono. 2006. Metode Penelitian Bisnis. Cetakan ke 4. Bandung: Alfabeta. 